\title{
Multicultural Values on Poetry Collection of Air Kata Kata by Sindhunata in Social Semiotic Perspective
}

\author{
${ }^{1}$ Siti Fatimah, ${ }^{2}$ Joko Nurkamto, ${ }^{3}$ Budi Setiawan, ${ }^{4}$ Ngadiso \\ ${ }^{1}$ fatimah_juwana@yahoo.com, ${ }^{2}$ jokonurkamto@gmail.com, ${ }^{3}$ buset.74@gmail.com, \\ ${ }^{4}$ ngadisodok@yahoo.com \\ 1,2,3Pendidikan Bahasa Indonesia Universitas Sebelas Maret Surakarta, Indonesia
}

\begin{abstract}
Poetry is a means to convey the poet's messages, such as the message of unity which persuades to unite despite of different ethnicity, religion and race. It seems that through his poetry collections of Air Kata Kata, Sindhunata conveys the messages through his poems. It is proven by the multicultural values which implicitly found in his poems. Therefore, social semiotic is used in this study in order to obtain those multicultural messages. Based on the analysis, there are found multicultural messages in Sindhunata's poems and it is worthy to be imitated by the readers. The result of the study becomes substantial, because the messages which find in a literature work, especially poetry, is able to change someone's mindset and lifestyle whether in present or in the future.
\end{abstract}

Keywords: multicultural; Air Kata Kata Poetry; social semiotic; Sindhunata.

\section{Introduction}

A poetry by Sindhunata are difficult to understand. In addition to being inspired by certain social phenomena in a certain period of time in poetry, there are symbols that must be interpreted more deeply in the texts and images contained in the anthology of Air Kata Kata poetry by Sindhunata. Therefore, social semiotics is used to express meaning through symbols contained in images and key words in poetry texts, especially multicultural values.

A research related to multicultural values is very important for readers to know, so that they can be exemplified, it is given that various problems come from racism, differences of opinion, disagreements with a view of life, different ethnicities, misconceptions in communication caused by differences in language, religion, and so on. Many provoking in society caused by differences in social and cultural status occurs in a protracted and difficult to find solution. However, with the anthology of Air Kata Kata poetry by Sindhunata, it can be used as a reference for reflection, self-reflection, evaluating actions and decisions that someone will take, and self-control to do things that cause divisions due to ethnic, cultural, religious differences and race.

The results of the research can be used by academics, religious leaders, literary people, and all people who feel that the national unity is a fixed price. Because of the limitations of a person in understanding poetry, especially Sindhunata poetry, the results of this study can be used to help understanding the audience. Furthermore, the reader can find out at the same time the multicultural values contained in the anthology of Air Kata Kata poetry by Sindhunata. Thus, the problem of division, war and quarrels in Indonesia in particular, and in the world in general, can be minimized.

\section{Literature Review}

Research relevant to this research was conducted by Furr dam Funder[1] entitled $A$ Multimodal Analysis of Personal Negativity focusing on unhappiness and dissatisfaction with 
regard to behavior, self-perception, social reputation, and the way people are treated by others. The study is considered still relevant to the research conducted in relation to multimodal use although the study focus is different. The difference between them is the type of Furr and Funder research in the psychological field while the research that is being carried out in the field of literature.

Research of Exploring Learning Through Visual, Actional and Linguistic Communication: The Multimodal Environment of a Science Classroom by Jewitt and Kress[2] is relevant to research that is now carried out because it is used as a multimodal approach. Jewitt and Kress et al did research on learning that is realized through the interaction between visual, acting and linguistic communication (i.e. multimodal learning) and involves transforming information across different communicative systems (modes), for example from speech to pictures. Meanwhile, to reveal the symbolic meaning of the anthology of Air Kata Kata poetry is used multimodally in the research that is now carried out.

Iedema[3] with a study entitled Multimodality, Resemiotization: Extending The Analysis of Discourse as a Multi-Semiotic Practice argues that resemiotization is intended to provide an analytical means to (1) trace semiotics translated from one to another when the social process takes place (2) ask the reason for the choice of semiotics (rather than others) mobilized to do certain things at certain times. This article refers to various empirical data to provide examples of two perspectives on visual communication and analysis. Iedema research is considered still relevant to the research carried out as far as it is concerned with the use of social and multimodal semiotics.

Harrison[4] with the title of Social Semiotic Visual: Understanding How Still Images Make Meaning explains two things, namely 1) understanding how text and images blend together to create shared meanings for the reader, 2) know when images can improve or reduce (meaning) text and vice versa, and 3) be able to effectively discuss the problem of multimodal communication with other members of the document production team. Obviously, Harrison's research is in line with the research being carried out, because there are texts (writings) and drawings/ paintings in the anthology of Air Kata Kata poetry that need to be interpreted, both referred to as multimodal text, and equally analyzed using social semiotics.

Thurlow and Aiello[5] in National Global Capital: a Social Semiotic Analysis of Transnational Visual Branding in The Airline Industry analyzes the results of which can overcome the problems faced by airlines. In the end, the airlines can serve the issue of national identity through the use of very local visual meanings while also appealing to the system of international market meaning in pursuit of symbolic and economic capital. One of the key sources of semiotics is the balancing of cultural symbolism and perceptual the iconism in the form of abstract stylizations of kinetic effects. Although social and multimodal semiotics is used for the development of a company, the research is considered still relevant to the current research, in terms of using the perspective of social semiotics with multimodal support to interpret the symbols contained in the anthology of Air Kata Kata poetry by Sindhunata.

Bezemer and Kress[6] in Writing in Multimodal Text: a Semiotic Account of Design for Learning constructs learning devices based on social semiotics and multimodal texts. It was explained that there were changes in the use and form of writing, which was caused by social, pedagogical and semiotic influences. These changes are due to two things as a sign, namely the existence of digital media as a source of learning and exchange of information and writing and changing drawing as a central mode for representation. The perspective used in the same study is semiotic social with multimodal text but the object of study is different. Writing learning is the focus of the study in Bezemer and Kress's research, while the symbol contained 
in the anthology of Air Kata Kata poetry by Sindhunata is the focus of the research being carried out.

Serafini[7] through Multimodal Reading Text: Perceptual, Structural, and Ideological Perspectives are considered relevant to the research currently being carried out. Serafini reads using multimodal with 3 concepts, namely (1) perceptual, (2) structural, and (3) analytical ideological processes for interpreting text. Some texts are investigated with semiotics, art theory, visual grammar, communication studies, media literacy, visual literacy and literary theory. Interpretation is seen as more efficient with visual, textual and design elements that the reader has in interpreting the text. This is in accordance with the purpose of using multimodal in the study of the anthology of Air Kata Kata poetry, which is to uncover symbols in poetry texts.

Ryan[8] in Improving Writing Reflective in Higher Education: a Social Semiotic Perspective explains that reflective writing is complicated, and has high rhetorical demands, making it difficult to master unless taught explicitly and systematically. Therefore, a functional semantic approach to language is used based on the semiotics of the systemic functional linguistic social linguistics that can be used to develop social semiotics models for reflective writing. The relevance of this research with the current research is the use of social semiotics and the difference is only in the focus of the study, namely writing reflective in college and symbolic meaning through convention and socio-cultural society in the anthology of Air Kata Kata poetry.

O'Halloran[9] through a study entitled Multimodal Discourse Analysis does the study of language combined with other resources such as images, scientific symbolism, cues, actions, music, and sound. The research is relevant to research that is now being carried out, namely on the use of social and multimodal semiotics.

Meanwhile, research related to the anthology of Air Kata Kata poetry that have been carried out titled Relation of Picture Illustration with Air Kata Kata Poetry by Sindhunata [10] and is a qualitative research. Fatimah mentions the paintings contained in the anthology of Air Kata Kata poetry as illustrative images. In addition, it is also mentioned that the relation between poetry text and illustration image is the relation or attachment relationship and the connection of meaning, which is expressed using semiotics also to reveal symbols in poetry texts and illustration images, but not social semiotics.

Mandasari[11] conducted a study entitled Religious Poetry of Air Kata Kata Poetry by Sindhunata. The results of research related to religious studies include the involvement of 1) ritual, 2) ideological, 3) intellectual, 4) experimental, and 5) consistent in Air Kata Kata poetry by Sindhunata. Although the study object is the same as the research being carried out, the focus of the study and the theory used is different.

Research entitled Forms and Types of Prismatic Poetry in a Anthology of Air Kata Kata Poetry by Sindhunata were also carried out by Fatimah[12]. Also used semiotics, but not social semiotics, and the results of qualitative descriptive research are 1) the forms and types of prismatic poetry that are in the anthology of Air Kata Kata poetry are classified into new genres, there are two types of terms to refer to the genre, namely mbeling poetry (if viewed from the unconventional physical and mental structure) and rinupa poetry (if viewed based on a combination of poetry texts and images contained in them).

Another study was conducted by Sartika[13] entitled Social Criticism in the Anthology of Air Kata Kata Poetry by Sindhunata: Study of Post-Structural Semiotics. The object of the research study is the same as the object of study in the current study. In her research, Sartika uses post-structural semiotics, not social semiotics even though it examines similar things related to social. The results of the research are 1) criticized social problems in the anthology 
of Air Kata Kata poetry by Sindhunata, 2) the social conditions of the community which are the background of the creation of the anthology of Air Kata Kata poetry by Sindhunata, and 3) the aesthetic method used to convey criticism social and sign relations in the anthology of Air Kata Kata poetry by Sindhunata. Judging from the problems studied, there are similarities with the research being carried out, the difference is in the theory used and the interpretation process carried out.

In a study entitled Persuasive Language Features on Multimodal Text of the Indonesian Version of the Oriflame Perfume Catalog of July 2014 Edition by Ulfa[14], it was explained that advertising was used to invite people through various sign systems. Therefore, advertisers must pay attention to attractive images and persuasive language. This is included in the document analysis because it is applied to written advertisements by analyzing the combination of sign systems. This shows that the advertiser considers the strategy and the sensitivity of various characteristics of persuasive language in order to obtain an expected action from the reader to buy the product. This research is considered relevant to the research being carried out, namely on scalpel, using social semiotics.

In addition, research related to multicultural values, relevant research conducted by Honna[15] entitled English as a Multicultural Language in Asia and Intercultural Literacy. The study stated that the use of English is not only used by Americans or English people, but by Chinese, Koreans, Bruneians, Thais, Malaysians, Singaporeans, and other Asians, Europeans, Africans, Arabians, and South Americans. English is the language of multinational communication.

The multicultural concept comes from Dawam[16], namely cultural diversity, various politeness, and / or a lot of maintenance. Multiculturalism can also be interpreted to be free of racism, sexism and other forms of social domination and intolerance[17]. Meanwhile, Aly[18] stated that multiculturalism is to recognize, accept, appreciate, and celebrate cultural diversity.

In addition, Rosyada[19] said that multiculturalism is to build the strength of a nation which consists of various ethnic, religious, racial, cultural and linguistic backgrounds, by respecting and respecting their civil rights, including rights minority group. In addition, multiculturalism can be interpreted as a rejection of bigotry, prejudice, racism, tribalism and accepting inclusive diversity[20]. Multiculturalism can also be interpreted to focus on understanding and living together in different socio-cultural contexts[21].

Meanwhile, research that is considered relevant is entitled Humanism and Multiculturalism: an Evolutionary Alliance by Diaz[22]. In the study, it was revealed that humanism and multiculturalism are partners in evolutionary alliances. Humanistic and multicultural psychotherapy has historically influenced each other. Humanism represents a third power in psychotherapy, while multiculturalism embodies the fourth stage of development. Multiculturalism embraces human values based on the context of collective and social justice. Examples of multicultural human construction include contextualism, holism, and liberation. Of course, multicultural-humanistic relationships are important changes in the evolution of psychotherapy. Humanism and multiculturalism participate in the development of inclusive and evolutionary psychotherapy.

In addition, other relevant research was carried out by Muzayanah entitled The Role of the Islamic Education Subject and Local Tradition in Strengthening the Nationalism of the Border Society: Study in Temajuk Village Sambas Regency of West Borneo[23]. A qualitative approach is used to describe the function of the Saprahan tradition that is used to strengthen nationalism in border communities through Islamic religious education with 3 principles, namely unity, equality and performance. The three principles are in accordance with the 
values of nationalism, namely democracy, tolerance, unity and harmony. Multicultural values arise in the midst of local traditions owned by the plural Temajuk community.

Meanwhile, the use of social semiotics in this research is to uncover the multicultural value in the anthology of Air Kata Kata poetry by Sindhunata. Social semiotics is part of semiotics[4]. Halliday[24] argues that meaning in social semiotics and the structure of language is one of the semiotic systems that make up a culture, language is the potential for shared meanings which are inherently social, and in fact, language as a system of 'active symbolizes' social system, so from this perspective, that language is social semiotic, the exchange of meaning depends on the social context and the purpose of exchange.

Meanwhile, Halliday added that to find out / interpret the social context of the text or the meaning of a language in a text, it should be known the field of discourse, discourse involvement (tenor of discourse), and means of discourse[24]. Simply put, Halliday's thought can be explained that 1) the discourse field is related to everything that is happening, social action in an environment, involvement of someone in an event that is happening, and the most important component is the style of language used, 2) the involvement of discourse is speakers, speakers with characteristics, status, roles in society, types of relationships with their roles, and significance of dialogue based on social relations, and 3) means of discourse related to the role of language spoken, expectations of speakers with spoken language, collection symbol on the text, status and function that the symbol has in a context.

Based on studies conducted in previous studies, it is known that research under the title The Anthology of Air Kata Kata Poetry by Sindhunata in the Social Semiotics Perspective has never been done. This research is important to describe the multicultural values found in the anthology of Air Kata Kata poetry by Sindhunata. In addition, research on poetry has never been conducted with the perspective of social semiotics. Not only that, the anthology of Air Kata Kata poetry has also not been studied with social semiotics, although previous research has already highlighted social problems, but uses post-structural semiotics not social semiotics. The results of this study are considered new and can be used as additional references for readers, connoisseurs and literary experts, as well as further researchers.

\section{Material \& Methodology}

\subsection{Data}

The data in this study are key words in the poetry and symbol texts contained in the picture of the anthology of Air Kata Kata poetry by Sindhunata published in 195 pages by Galang Press and Bayu Media in 2004. There are 71 poetry titles, with details: 60 pictorial poetry title, 5 non-pictorial poetry titles, 4 poetry titles with drawings but no names of the characters, and 2 poetry titles with the names of the characters but no images. The whole poetry is categorized based on multicultural values, both pictorial and with no images.

\subsection{Method}

Qualitative descriptive research methods are used with content analysis in this study. Analyzed documents in the form of words and pictures/paintings to obtain multicultural values through the process of interpretation based on social semiotics reinforced by multimodal analysis. Thus, there are two capital that are analyzed to reveal the multicultural value in the collection of poems, namely words and pictures/paintings. 


\section{Results and Discussion}

\subsection{Result}

The multicultural value contained in the anthology of Air Kata Kata poetry by Sindhunata includes diversity of 1) language use, 2) culture, 3) social phenomena, 4) religion, and 5) ethnicity/race. Regarding cultural diversity, the multicultural value can be seen in the use of spells, traditional songs, tune and national songs even though the songs are slipped, puppet stories, names of people from various ethnic groups, and macapat songs.

Meanwhile, in terms of language use, various languages are used, namely Javanese, English, Indonesian, Manado, and Chinese. Not only that, there were also various social phenomena which were being discussed and polemic in its time, for example the Inul Daratista rocking, elections, child abduction, sexual harassment, and reform. The poet also expressed his thoughts on religious life, including various religions in his poems, both Islam, Catholicism, China, or even Islam of Javanese Culture (Kejawen) as one of the schools of belief. The poet also includes various ethnicities in his poems, ranging from Java, China and Manado.

For example, multicultural values can be seen in the fragment of the poetry entitled Jula Juli Guru below.

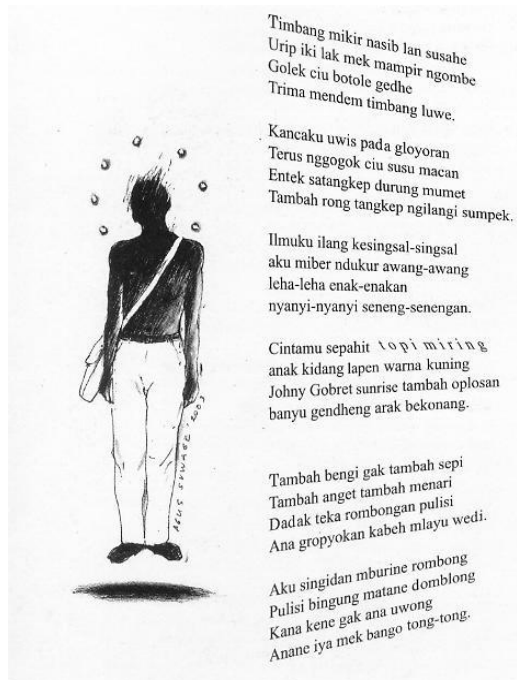

Picture 1. The Fragment of the Jula Juli Guru Poetry

In the fragment of Jula Juli Guru poetry above contains Javanese and Indonesian. In addition, the poetry is delivered in parikan or type of Javanese poetry. The social phenomenon contained in poetry questions the anomaly of the teacher's life, about salary, morals, needs and the reality of faced life.

The message contained in the Jula Juli Guru poetry is 1) being a low-paying teacher will not improve the quality of education because of busy part-time work, rather than busy developing material and abilities, 2) should be a role model teacher, not a teacher with bad morals often alcohol drunk, and 3) not only teachers, any type of work, including the police, is a shameful act if corruption.

The multiculturalism presented by Sindhunata can not only be found in the Jula Juli Guru poetry, which is conveyed in parikan style or the type of Javanese poetry, it can also be seen in the following Rep. Kedhep's poetry delivered by slipping dolanan songs into spells. 


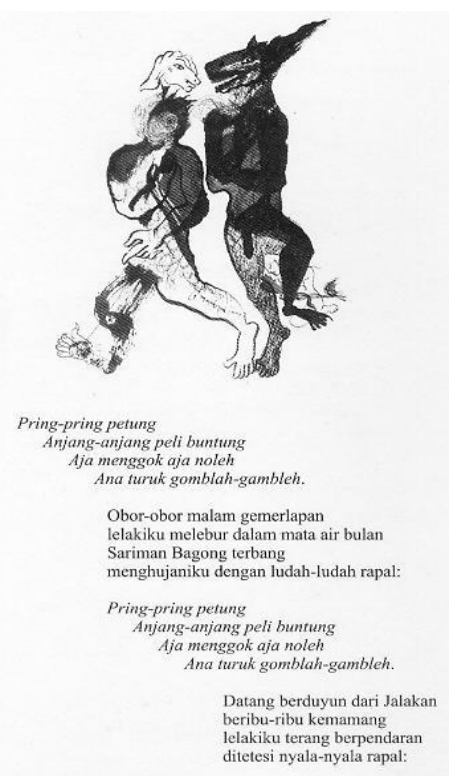

Picture 2. The Fragment of the Rep Kedhep Poetry

Javanese and Indonesian are used in Rep Kedhep's poetry above. The words in Javanese contain rapal or utterances that are often found for traditional games of Javanese children, but in the poetry it is converted into prayers to grow courage, strength, and power, with the keyword "my man" which can be interpreted as "maleness" or symbol of might.

Poetry on Jula-Juli Guru delivered with parikan style or type of Javanese poetry and Rep. Kedhep's poem was delivered by slipping dolanan songs into spells. There are also Sindhunata poetry conveyed in a spell style and do contain spells, which can be seen in the Mantra Tolak Bala and Wak Duljangjep poetry. In Mantra Tolak Bala poetry, Old Javanese is used which is very difficult to understand by people today. Not only that, there are several religions and beliefs in the Mantra Tolak Bala poetry, referred to as the Islamic Javanese group, namely Javanese Muslims. This group or group is usually Muslim but still uses Javanese worship, both in words and in procedures.

It can be seen in the third verse by using the words below.

Nyawaku nrima ing Allah

Nyawaku ngidhep ing Allah

Nyawaku ningali ing Allah

Panrimaku iman

Pangidhepku tokid

Paningalku makripat

Ya iku urip sejatiku:

Suminggaha kabeh sing Allah

Sumingkira kabeh sing dudu Allah 


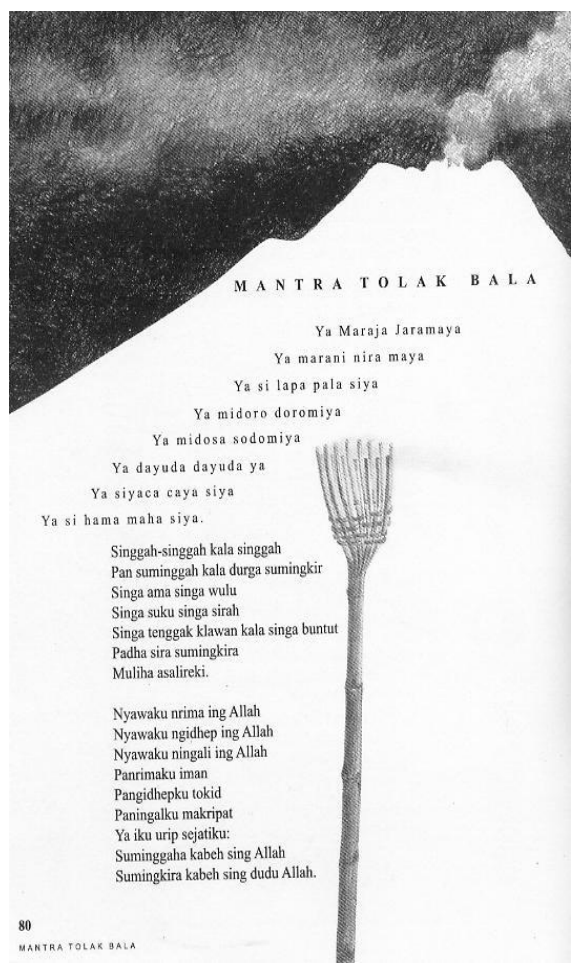

Picture 3. The Fragment of The Mantra Tolak Bala Poetry

The word of Allah is related to the religion of Islam, even though in Christianity and Catholicism God also uses it, but in the following words faith, tokid, and scriptures further strengthen the analysis that what is meant by God is the God of Islam. Thus, Sindhunata has an openness to the teachings of Islam even though he is a Catholic leader. Meanwhile, you can see images that resemble volcanoes and magic brooms, like those of wizards in films (Harry Potter for example), which symbolizes mysticism. Because it is related to the mantra, inevitability of the world is full of mystery and mysticism as symbolized by volcanoes and magic brooms.

The use of Indonesian and Javanese in one poetry title can also be found in the poetry of Wak Duljangkep. In the fragment of Wak Duljangkep poetry below, Indonesian is used as a whole, except for the words njedhul, jangkep-jangkepan, duljangkep, jagongan, and wedangan which are Javanese. Overall, this poem contains "the union of a person with his God", in other words, a human who feels his closeness to God. The God referred to in this poetry does not only belong to Muslims or Catholics (according to the religion believed by Sindhunata) but all religions and schools of belief. 


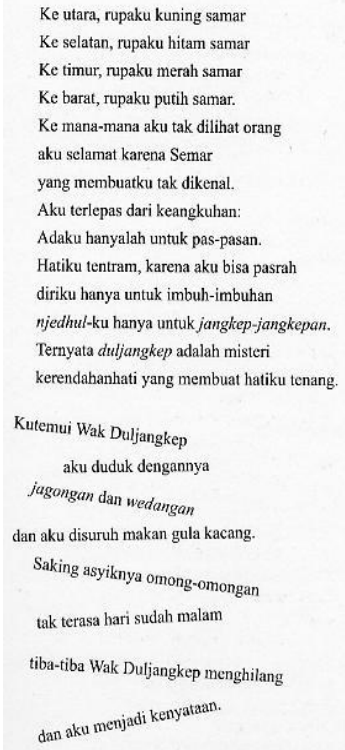

Picture 4. The Fragment of The Wak Duljangkep Poetry

Related to religion, Sindhunata also did a kind of translation of the Lir-Ilir song's poetry which was originally sung in Javanese and then associated with the religion people believed, namely Catholic. 
L I R - I L I R

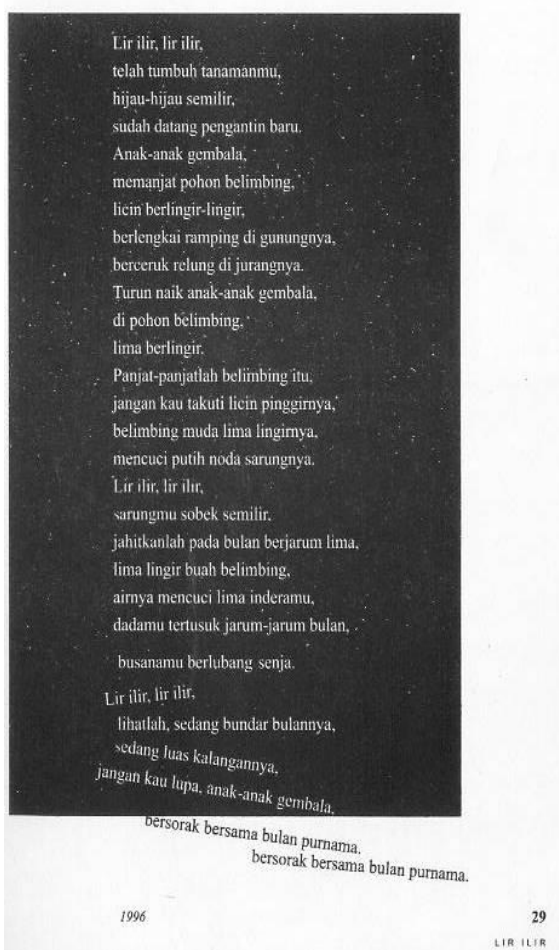

Picture 5. The Fragment of The Lir-Ilir Poetry

In Lir-Ilir poetry, Sindhunata combines the basis of Islamic religious beliefs and Catholicism, namely in the shepherd's children, who in the original song lyrics are called cah angon. Both the original song and the poem written by Sindhunata use the same title, namely Lir-Ilir. The Lir-Ilir song is used by Sunan Kalijaga in conveying the teachings of Islam to the public. meanwhile, Sindhunata seems to do the same according to his version and belief, considering that he is also a respected Catholic leader in Yogyakarta.

Regarding religion, Sindhunata wrote the Air Kata Kata poetry containing advice as a dead reminder. Every human being will eventually experience death, regardless of status, amount of wealth, ethnicity, religion, good character, language, and ethnicity, all will experience a funeral procession. In the poetry, Indonesian and Latin are used. Not only that, it was also used a campur sari song called Nyidham Sari which was slipped with the aim that the message delivered was more aesthetic and not patronizing. 


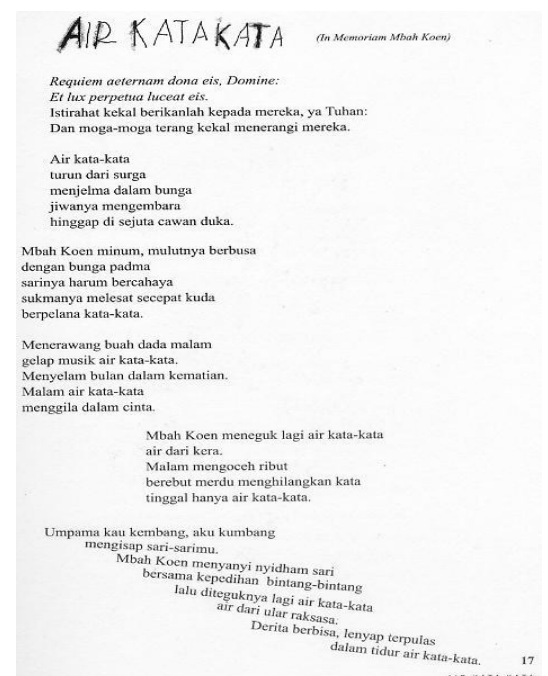

Picture 5. The Fragment of The Air Kata Kata Poetry

It can be seen from some of the poetry above, Sindhunata includes various aspects of different cultures, ethnicities and religions, but is mixed into a poetry that expresses unity despite differences. It seems that in this difference, readers are expected to be able to behave and act wisely so that there is no chaos in community life. Sindhunata poetry can be used as a mirror of a person in creating a harmonious life, both from himself and to others.

\subsection{Discussion}

Based on the research conducted, found the multicultural values that Sindhhunata expressed into the anthology of Air Kata Kata poetry. This multicultural value is seen in various religions and beliefs mentioned in poetry, both Islam, Catholicism, Javanese or kejawen beliefs, (Javanese Muslims). In addition, Sindhunata, which is Javanese and Catholic, includes spells used by Javanese, both in Javanese and Indonesian, traditional Javanese songs, national songs, intertwined songs, traditional games, puppet stories, parikan or types of Javanese poetry, and myths. Not only that, the characters in the poem are taken from the names of Chinese, Javanese, Manado, and various religious or religious traditions. One more, the depth of Sindhunata poetry lies in the philosophies of various ethnic groups, Javanese philosophy, China, and several verses from scripture (Islam, Catholicism, Buddhism, Hinduism, and other schools of faith) as advice to readers.

Based on data obtained through analysis using social semiotics, it can be seen that Sindhunata is a poet whose life is based on multicultural values. Sindhunata is a Catholic, comes from Java, but is familiar with the life-style of ethnic Chinese, Muslims, loves language, myths, and stories in Java, China, various religious scriptures (Buddhism, Hinduism, Kejawen), loves Javanese, Indonesian, Latin, Gospel, and English, and familiar with folk songs outside the life of the church. Not surprisingly, Sindhunata received the award of cultural conservationists on August 22 nd 2016 who contributed to developing Javanese literature through its various writings[25]. Sindhunata emanates through his poems, which can be read and enjoyed and exemplified by various ethnic groups, ethnicities, and religions, especially related to multicultural values. 


\section{Conclusion}

Multicultural values contain in the poetry anthology of Air Kata Kata can be seen from 1) various religions and beliefs mentioned in poetry, 2) spells, 3) parikan or Javanese poetry, 4) puppet stories, 5) macapat songs, 6) campur sari songs, 7) traditional games, 8) myths of various ethnic groups, 9) names of characters in poetry taken from various ethnic groups and scriptures of various religions, and 10) the inclusion of philosophies from various ethnic groups as advice to reader audience. Various aspects of multiculturalism are mixed with words that are very artistic, aesthetic, symbolic, and full of meaning. This multicultural value is important to be known and imitated by the reader in daily life, so that the anti-communal and antisocial mindset can be eroded, to realize the unity and integrity of the nation with a high sense of tolerance and nationality.

It should be realized that the language used by Sindhunata in the anthology of Air Kata Kata poetry is not easy to understand, therefore it requires a deep reading with various points of view. Therefore, this also opens up another space to conduct studies using different points of view in the future. Considering the meaning and various messages that are worthy of being known and exemplified by the reader, the next researchers can use the analysis in the perspective of literary anthropology, ethnology, intertextual, feminism, literary sociology, literary psychology, and another multidisciplinary that are considered relevant.

\section{Acknowledgement}

I would like to thank to Romo Sindhunata for allowing the researcher to analyze the poetry anthology of Air Kata Kata which is created by him. I also would like to gratefully thanks to Prof. Dr. Joko Nurkamto, M.Pd., Dr. Budi Setiawan, M.Pd., and Dr. Ngadiso, M.Pd., who has assisted to finish many years. Furthermore, I thank to Prof. Dr. Sarwiji Suwandi, M.Pd. who has greatly provided support in this research.

\section{References}

[1] D. C. F. R. Michael Furr, "A Multimodal Analysis of Personal Negativity," J. Pers. Soc. Psychol., vol. 74, No. 6, pp. 1580-1591, 1998.

[2] C. T. Jewitt, Carey, Gunther Kress, Jon Ogborn, "Exploring Learning Through Visual, Actional and Linguistic Communication: The Multimodal Environment of a Science Classroom," Educ. Rev. J., vol. 53 No.1, pp. 5-18, 2001.

[3] R. Iedema, Multimodality,Resemiotization: Extending The Analysis Of Discourse As Multi-Semiotic Practice. London: Sage, 2003.

[4] C. Harrison, "Visual Social Semiotic: Understanding How Still Images Make Meaning," Tech. Commun., vol. 50 No. 1, pp. 46-60, 2003.

[5] G. A. Crispin Thurlow, "National Global Capital: a Social Semiotic Analysis of Transnational Visual Branding in The Airline Industry," SAGE Publ., vol. 6 No. 3, pp. 305-344, 2007.

[6] and G. K. Jeff Bezemer, "Writing in Multimodal Text: a Semiotic Account of Design for Learning," Writ. Commun. J., vol. 25 Number, 2010.

[7] F. Serafini, "Reading Multimodal Text: Perceptual, Structural, and Ideological Perspectives," Springer J. Child. Lit. Educ., vol. 41, pp. 85-104, 2010.

[8] M. Ryan, "Improving Writing Reflective in Higher Education: a Social Semiotic Perspective," J. Teach. Educ., 2010.

[9] K. L. O’Halloran, Multimodal Discourse Analysis. London and New York: Continuum, 2011.

[10] S. Fatimah, "Relasi Gambar Ilustrasi dengan Teks Puisi Air Kata Kata Karya 
Sindhunata," Universitas Negeri Semarang, 2008.

[11] R. R. Mandasari, "Kajian Religius Puisi Air Kata Kata Karya Sindhunata," Universitas Jember, 2006.

[12] S. Fatimah, "Bentuk dan Jenis Puisi Prismatis dalam Kumpulan Puisi Air Kata Kata Karya Sindhunata," J. MALIH PEDDAS, vol. 3 Nomor 2, 2013.

[13] R. E. A. Sartika, "Kritik Sosial dalam Kumpulan Puisi Air Kata Kata Karya Sindhunata: Kajian Semiotika Post-Struktural," Universitas Negeri Yogyakarta, 2014.

[14] M. Ulfa, "Persuasive Language Features On Multimodal Text Of Indonesian Version Of Oriflame Perfume Catalogue Of July 2014 Edition," Universitas Brawijaya, 2015.

[15] N. Honna, "English as a Multicultural Language in Asia and Intercultural Literacy," Intercult. Commun. Stud. J., vol. XIV. No. 2, 2005.

[16] M. D. Rahardjo, Perkembangan Masyarakat dalam Perspektif Pesantren, Pergulatan Dunia Pesantren: Membangun dari Bawah. Jakarta: P3M, 1985.

[17] F. Hidalgo, Multicultural Education Landscape for Reform in the Twently-first Century. New York: Pergamon, 2001.

[18] A. Abdullah, "Studi Deskriptif Tentang Nilai-Nilai Multikultural dalam Pendidikan di Pondok Pesantren Modern Islam Assalaam," J. Ilm. Pesantren, vol. I, No. 1, 2015.

[19] D. Rosyada, "Pendidikan Multikultural di Indonesia Sebuah Pandangan Konsepsional," Sosio Didakt., vol. 1, No.1, 2014.

[20] W. A. Haviland, Antropologi 2. Jakarta: Erlangga, 1988.

[21] B. Fay, Contemporary Philosophy of Social Science: A Multicultural Approach. Massachusetts: Blank Well Publishers Ltd, 1998.

[22] L. C. Diaz, "Humanism and Multiculturalism: an Evolutionary Alliance," Psychoter. J., vol. 49. No. 4, pp. 437-441, 2012.

[23] U. Muzayanah, "The Role of The Islamic Education Subject and Local Tradition in Strengthening Nationalism of The Border Society: Study in Temajuk Village Sambas Regency of West Borneo," Anal. J. Soc. Sci. Relig., vol. Vol. 2 No., 2017.

[24] M. A. K. Halliday, Language as Social Semiotic: The Social Interpretation of Langauage and Meaning. London: Edward Arnold, 1978.

[25] Kompas, "No Title," p. 1 and 6. 